\title{
Cathode catalytic dependency behavior on ionomer content in direct methanol fuel cells
}

\author{
Zhi Long a,b, Guangrong Deng a,c, Changpeng Liu ${ }^{\text {a,d }}$, Junjie Ge ${ }^{\text {a,d }}$, Wei Xing a,d,*, Shuhua Ma ${ }^{\text {b,\# }}$ \\ a State Key Laboratory of Electroanalytical Chemistry, Changchun Institute of Applied Chemistry, Chinese Academy of Sciences, Changchun 130022, Jilin, \\ China \\ b Shandong Provincial Key Laboratory of Fluorine Chemical Materials, School of Chemistry and Chemical Engineering, University of Jinan, Jinan 250022, \\ Shandong, China \\ c University of Chinese Academy of Sciences, Beijing 100049, China \\ ${ }^{\mathrm{d}}$ Laboratory of Advanced Power Sources, Changchun Institute of Applied Chemistry, Chinese Academy of Sciences, Changchun 130022, Jilin, China
}

\section{A R T I C L E I N F O}

Article history:

Received 29 March 2016

Accepted 3 May 2016

Published 5 July 2016

\section{Keywords:}

Direct methanol fuel cells

Catalyst layer

Nafion

Cathode

Ionomer

\begin{abstract}
A B S T R A C T
Cathode catalyst layers (CLs) with varying ionomer (Nafion) contents were prepared and the direct methanol fuel cell structure and catalytic behavior were investigated as a function of ionomer content. CL roughness and thickness increased with increasing Nafion content. Contact angle measurements determined that CL hydrophilicity also increased as a function of Nafion content. Poor bonding between the $\mathrm{CL}$, microporous layer, and the proton exchange membrane was obtained when the ionomer content was too low. The electrochemical surface areas (ESAs) were found to increase with increasing Nafion content before reaching an asymptote at elevated loading levels. However, upon increasing the ionomer content above $30 \mathrm{wt} . \%$, the water and oxygen mass transfer properties were difficult to control. Considering the above conditions, N30 (30 wt.\% Nafion) was found to be the optimal level to effectively extend the three-phase boundaries and enhance cell performance.
\end{abstract}

(C) 2016, Dalian Institute of Chemical Physics, Chinese Academy of Sciences. Published by Elsevier B.V. All rights reserved.
Over the past few decades, direct methanol fuel cells (DMFCs) have attracted significant attention as a potential candidate for environmentally friendly energy conversion devices. Compared with hydrogen proton exchange membrane fuel cells (PEMFCs), DMFCs are safer to operate because of the liquid characteristics of methanol fuel [1,2]. A membrane electrode assembly (MEA) is a central part of DMFCs $[3,4]$. A MEA usually consists of a gas diffusion layer (GDL) having a microporous layer (MPL), a catalyst layer, and a proton exchange membrane (PEM). The GDL controls water, gas, and electron transfer [5-7]. PEMs transfer protons and separate fuel from oxygen.
The cathode catalyst layer (CL) is the crucial zone of the electrochemical reaction. The heterogeneous reaction occurs at a three-phase boundary comprising reactants, catalysts and an electrolyte [8]. The state-of-the-art catalysts used for methanol oxidation and oxygen reduction are $\mathrm{PtRu} / \mathrm{C}$ and $\mathrm{Pt} / \mathrm{C}$, respectively. The electrolyte is an perfluorosulfonic acid polymer, such as Nafion $[9,10]$. There are numerous reports investigating the detailed structure of CLs in PEMFCs, which have led to improvements in cell performance through optimizing the CL structure [9,11-20]. Xing et al. [20] presented a two-dimensional, two-phase flow model detailing how ionomer swelling

\footnotetext{
* Corresponding author. Tel: +86-431-85262223 ; Fax: +86-431-85685653; E-mail: xingwei@ciac.ac.cn

\# Corresponding author. Tel: +86-531-82769776; E-mail: chm_mashh@ujn.edu.cn

This work was supported by the National Basic Research Program of China (973 Program, 2012CB932800), the National Natural Science Foundation of China (21433003, 21373199), and the Science \& Technology Research Programs of Jilin Province (20150101066JC, 20160622037JC). DOI: 10.1016/S1872-2067(16)62481-6 | http://www.sciencedirect.com/science/journal/18722067 | Chin. J. Catal., Vol. 37, No. 7, July 2016
} 
results in both a decrease in cathode CL porosity and an increase in the ionomer coating thickness, thereby increasing the oxygen transport resistance. Optimal cell performance in the presence of fully humidified gases utilizes an initial dry ionomer volume fraction (initial ionomer content) close to $10 \%$, corresponding to $0.3 \mathrm{mg} / \mathrm{cm}^{2}$. Mashio et al. [21] employed a mathematical model to analyze the water sorption isotherm of PEMFC catalyst layers and observed water adsorption in the CLs initiates on the adsorption sites. Soboleva et al. [22] reported that ionomer co-deposition in the CL strongly influenced its porosity, covering a pore range $<20 \mathrm{~nm}$, which originated from the microporous nature of the carbon particles (pore sizes $<2 \mathrm{~nm}$ ) and the agglomeration of the carbon particles (pore sizes of 2-20 nm). Passalacqua et al. [23] investigated Nafion content in the PEMFC catalyst layer and observed the optimal ionomer content to be $\sim 33$ wt.\%. Multiple investigations have reported hybrid and multi-graded catalyst layer combinations to optimize the function of the CL in PEMFCs [24-27]. Lee et al. [28] designed a hybrid anode CL to study methanol and water transport in DMFCs. However, there are few reports studying the optimization of cathode CLs in DMFCs.

Herein, cathode CLs were prepared as a function of ionomer content and the influence on the cell structure and catalytic behavior was investigated. Electrochemical surface areas (ESAs) were found to increase with increasing Nafion content until a constant value was reached. Additionally, further increasing the ionomer content beyond this threshold level results in the inability to control water and oxygen mass transfer effectively. N30 (30 wt.\% Nafion content) is found to be the optimal level to effectively extend the three-phase boundaries, improving cell performance.

In our experiment, MEAs were prepared as follows: the MPL ink was prepared by mixing Vulcan XC-72 carbon with PTFE (25 wt.\%), followed by spraying onto carbon paper (anode: TGPH060, 20 wt.\% PTFE; cathode: TGPH090, 20 wt.\% PTFE). The carbon loading was $1 \mathrm{mg} / \mathrm{cm}^{2}$. The MPL-treated carbon paper was heat-treated at $320^{\circ} \mathrm{C}$ for $0.5 \mathrm{~h}$ to prepare the GDL. The anode and cathode catalysts were Pt40\%Ru20\%/C and Pt60\%/C (Johnson Matthey Corp.), respectively. The catalyst ink was prepared by dispersing the catalysts and $5 \mathrm{wt}$.\% Nafion solution in a solution composed of water and isopropanol $(v: v=$ $2: 3)$. Subsequently, the ink was sprayed onto the prepared GDL at $60{ }^{\circ} \mathrm{C}$ to form the gas diffusion electrode (GDE). Precious metal loading with respect to the anode was controlled at 2 $\mathrm{mg} / \mathrm{cm}^{2}$, and the content of Nafion was fixed at $25 \mathrm{wt} . \%$. Pt loading at the cathode was also $2 \mathrm{mg} / \mathrm{cm}^{2}$; however, the Nafion content varied at: $15,25,30,35$ and 45 wt.\%, respectively. Thereafter, the MEA was prepared by hot-pressing the electrodes on two sides of Nafion 115 at $135{ }^{\circ} \mathrm{C}$ at $7.5 \mathrm{MPa}$ for 2 min. The electrode area was $9 \mathrm{~cm}^{2}$, and the MEAs were named as N15, N25, N30, N35 and N45 corresponding to the Nafion content at the cathode.

The cyclic voltammetry (CV) tests of MEAs were performed with an EG\&G model 273 potentiostat/Galvanostat (Oak Ridge, USA). The cathode was employed as the working electrode and the dynamic hydrogen electrode (DHE) at the anode was used as the reference electrode and counter electrode. Deionized water at $35{ }^{\circ} \mathrm{C}$ was bubbled to the cathode at a flow rate of 8.5 $\mathrm{mL} / \mathrm{min}$, whereas hydrogen was bubbled to the anode at a flow rate of $150 \mathrm{~mL} / \mathrm{min}$. The cell remained at a constant temperature of $35{ }^{\circ} \mathrm{C}$ throughout the duration of the test. The potential window was $0-0.8 \mathrm{~V}$ at a scan rate of $50 \mathrm{mV} / \mathrm{s}$.

The polar curve of the single cell having an active area of 9 $\mathrm{cm}^{2}$ was evaluated using an Arbin FCT test station (Arbin Instrument Inc., USA). Methanol flow rate ( $2 \mathrm{~mol} / \mathrm{L})$ and $\mathrm{O}_{2}$ were fixed at $6 \mathrm{~mL} / \mathrm{min}$ and $0.5 \mathrm{~L} / \mathrm{min}$, respectively. All performance measurements were performed at 60 and $70{ }^{\circ} \mathrm{C}$. Electrochemical testing measurements and operating conditions are shown in Table 1.

The CL hydrophobic character with varying Nafion content was investigated using a drop-shape analysis system, DSA30 (KRUSS, Hamburg, Germany). CL surface morphology and roughness was observed by a $3 \mathrm{D}$ non-contact optical surface profilometer (Nanovea, California, USA) and scanning electron microscope (SEM, Philips XL30, field emission gun environmental SEM operating at $20 \mathrm{kV}$, Amsterdam, Netherlands).

The surface morphologies of the GDEs possessing varying Nafion contents were investigated using SEM and a 3D non-contact optical surface profilometer. 2D contour plots and the 3D surface morphology of the CLs are shown in Fig. 1. The CL roughness and thickness increased as a function of increasing Nafion content. As shown, the surfaces of N15 and N25 are relatively flat. Further increases in Nafion content result in a greater degree of surface roughness, as indicated by the higher peak densities homogeneously distributed across the sample. The area of sample studied, as indicated by the scale bars, is $5 \times 5 \mathrm{~mm}^{2}$; therefore it can be observed that as surface roughness increases, the resulting micrometer-sized pores also increase; this may facilitate the mass transfer process. As shown in Fig. 2, increasing Nafion content resulted in the formation of a cracked surface with the gap between the islands extending farther apart as a function of increased Nafion content. The surface of N15 and N25 were relatively flat when compared with higher Nafion loadings. Significant gaps initially appear upon increasing Nafion loading to between 30 wt.\% (N30) and 45 wt.\% (N45). The results were consistent with 3D surface morphology observations of the CLs. Regarding the microstructure, observations reveal that the granular structure changed to a flocculent-type structure with increased Nafion loading. The granular structure mainly reflected the microstructure of the catalysts, whereas the flocculent-type structure originated from the microstructure of the Nafion ionomer. Ad-

Table 1

Electrochemical test measurements and operating conditions.

\begin{tabular}{ll}
\hline Measurement & Operating conditions \\
\hline $\mathrm{CV}$ & Working electrode: the cathode with flowing water \\
& Reference and counter electrode: DHE at the anode \\
& Operating temperature: $35^{\circ} \mathrm{C}$ \\
& Potential window: $0-0.8 \mathrm{~V}$ \\
& Scan rate: $50 \mathrm{mV} / \mathrm{s}$ \\
Polarization & Active area of the single cell: $9 \mathrm{~cm}^{2}$ \\
curve & Methanol flow rate: $6 \mathrm{~mL} / \mathrm{min}$ \\
& O flow rate: $0.5 \mathrm{~L} / \mathrm{min}$ \\
& Operating temperature: $60-70^{\circ} \mathrm{C}$ \\
\hline
\end{tabular}



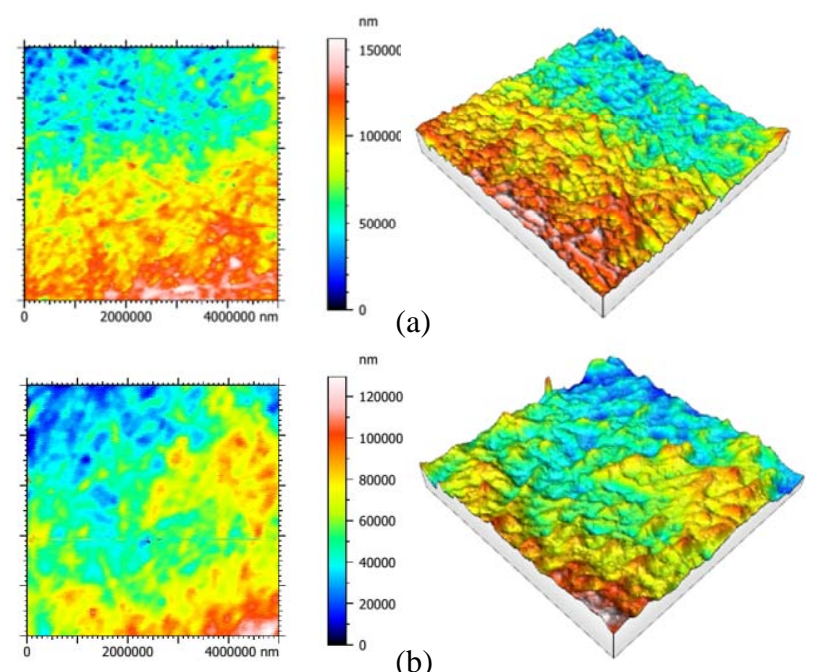

(b)
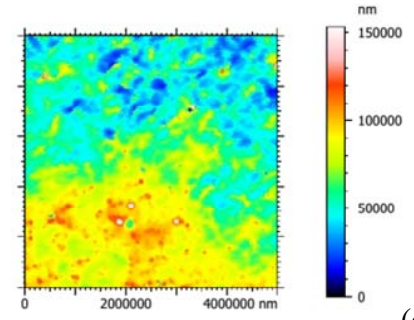

(c)
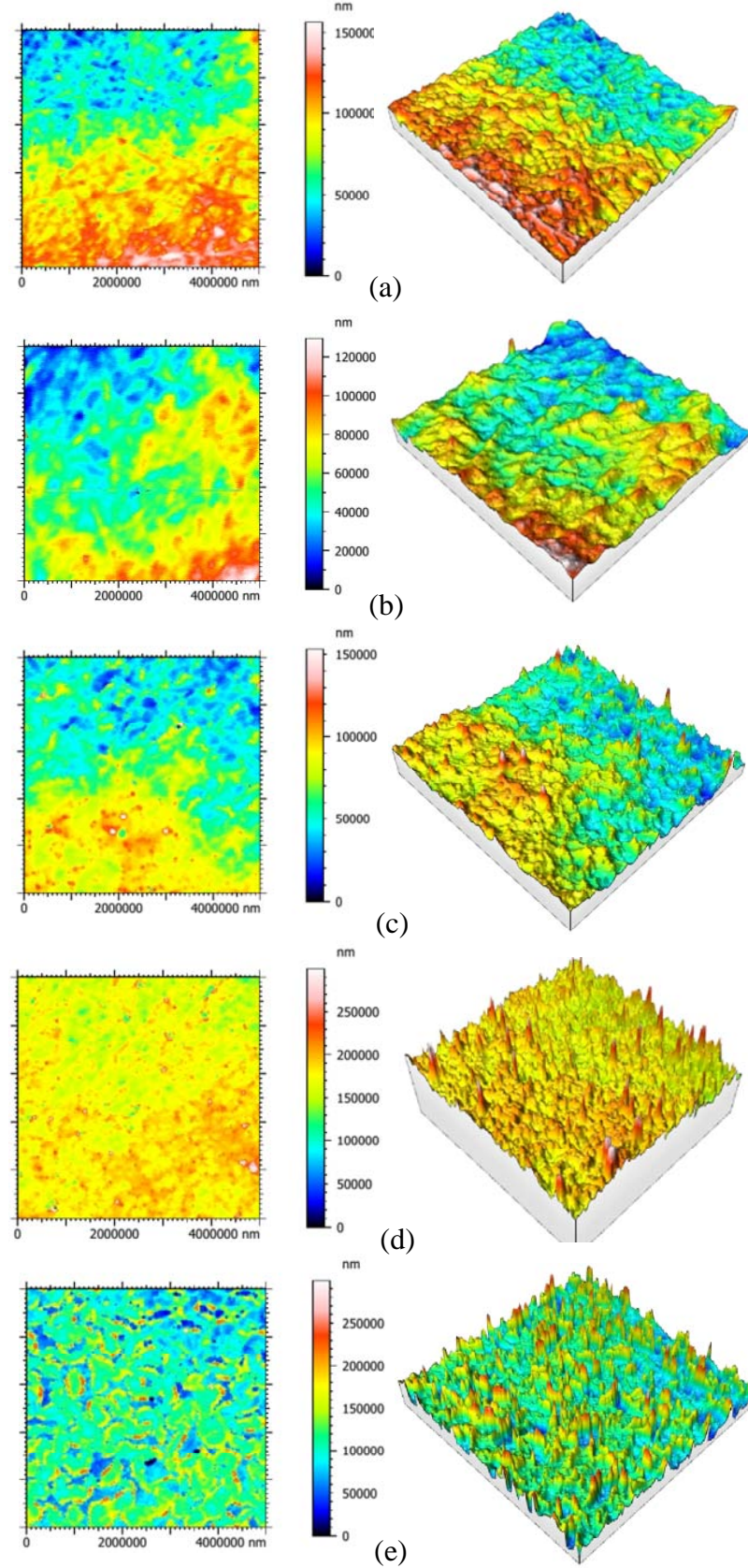

(d)
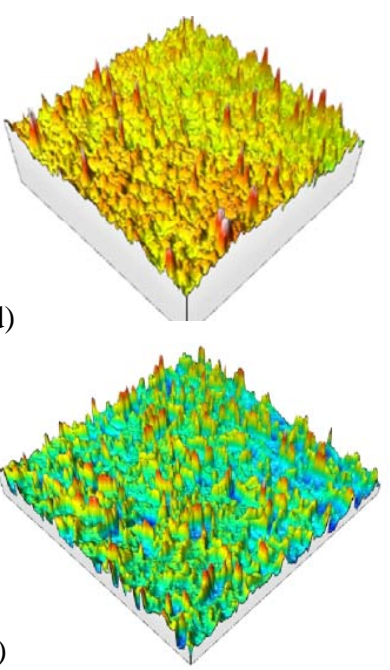

Fig. 1. 2D contour plots and 3D surface morphologies of catalyst layers (CLs). (a) N15; (b) N25; (c) N30; (d) N35; (e) N45.

ditionally, we found that GDE performance declined dramatically with lower Nafion contents because Nafion acts not only as a proton conductive material but also as the binder in the CL. Therefore, CLs with lower Nafion contents exhibit poor bonding with the MPL and proton exchange membrane.

The sulfonic functionality on the Nafion increases its hydrophilic nature when compared with the catalysts; and as a result, the contact angle decreases as a function of increasing Nafion content in the CL. As seen in Fig. 3, the contact angles decrease from $166.8^{\circ}$ to $143.1^{\circ}$ as Nafion loading increases from 15 to $45 \mathrm{wt} . \%$. The hydrophobicity of the CLs directly affects the mass transfer of liquid and gases, thereby affecting the DMFC cell performance. Cathode CLs are easily flooded
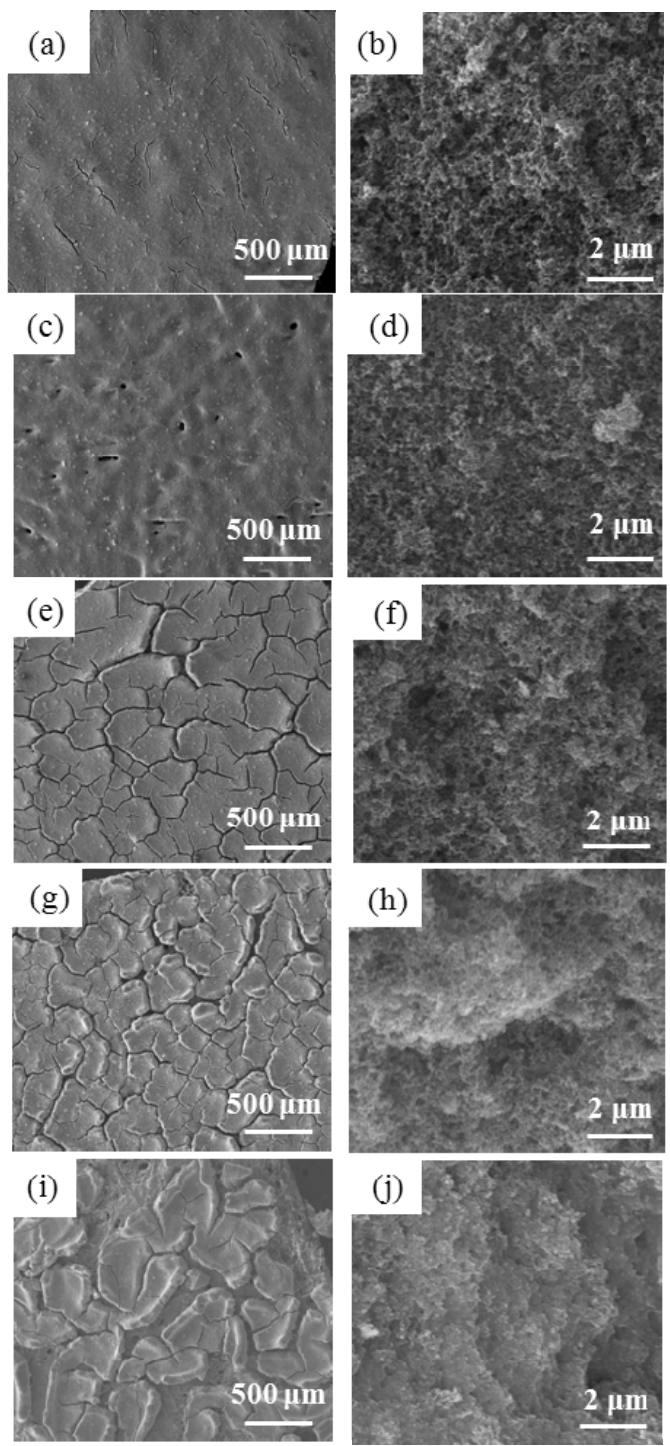

Fig. 2. Scanning electron microscopy images of gas diffusion electrodes. (a, b) N15; (c, d) N25; (e, f) N30; (g, h) N35; (i, j) N45.

because the hydrophilicity increases such that the water generated by the reaction is unable to be removed efficiently, thus blocking the pores for efficient mass transfer.

Cyclic voltammetry (CV) is an effective approach to evaluate the utilization of Pt nanoparticles (NPs) in the CL. As shown in Fig. 4, in-situ CV was tested for DMFCs with varying Nafion loading at the cathode CL. The cathodes adopting Pt/C catalyst showed larger current density for proton adsorption/desorption (around $0.3 \mathrm{~V}$ ) and double layer charging (around $0.45 \mathrm{~V}$ ). The EAS obtained from the integrated charge for electrochemical proton desorption without double layer charging. As shown, ESA increases as a function of Nafion content. At low ionomer content, such as N15, the majority of Pt NPs are not in direct contact with the continuous ionomer phase, thus becoming inactive for proton transfer. Adjusting the Nafion content from 15 to $25 \mathrm{wt} . \%$ results in a sharp increase in ESA. However, when the Nafion mass percentage is increased to more than $35 \mathrm{wt} . \%$, no obvious increase in ESA is observed, which is limited by the Pt loading $\left(2 \mathrm{mg} / \mathrm{cm}^{2}\right)$. Therefore, a 
(a) $166.8^{\circ}$

(b) $163.6^{\circ}$

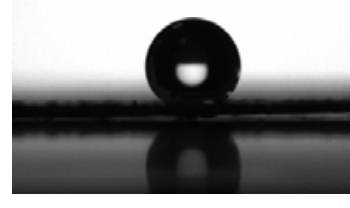

(c) $160.2^{\circ}$
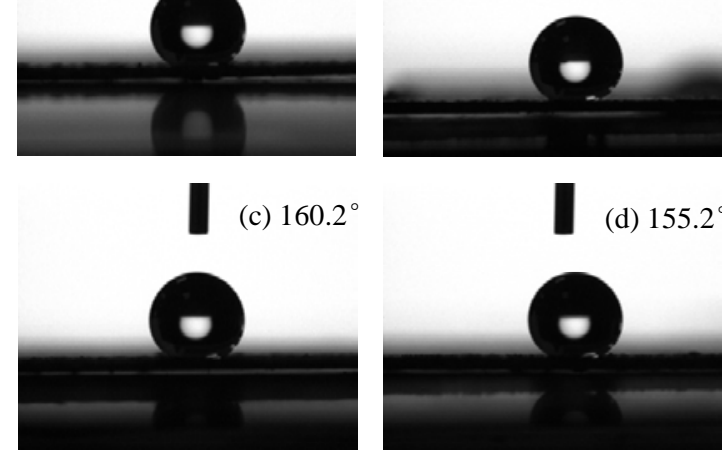

(d) $155.2^{\circ}$

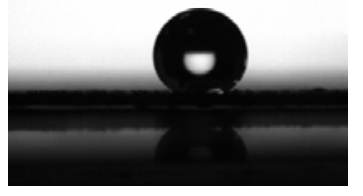

(e) $143.1^{\circ}$

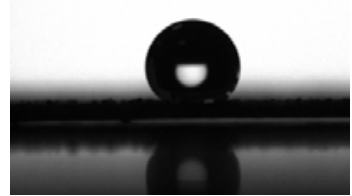

Fig. 3. Contact angles of water distributed on the cathode CL. (a) N15; (b) N25; (c) N30; (d) N35; (e) N45.

Nafion loading of 35 wt.\% was found to be optimal for the Pt NP ESA. Total coverage of Pt NPs only allows $\mathrm{O}_{2}$ dissolved in Nafion to contact the surface of the catalysts. Thus, cell mass transfer processes are also influenced by the ionomer content; therefore, it is preferable to directly measure the optimal CL Nafion loading from in-situ cell tests.

All performance measurements were conducted at 60 or 70 ${ }^{\circ} \mathrm{C}$. Fig. 5(a) shows the polarization curves of DMFCs with varying Nafion content at $60{ }^{\circ} \mathrm{C}$. Single cell performance increases as a function of increasing Nafion content when $<30 \mathrm{wt} . \%$, which can be ascribed to the increase in the catalyst utilization due to the facilitated proton mass transfer. However, further increasing the Nafion content beyond $30 \mathrm{wt} \%$ results in a decrease in the cell performance, which may be ascribed to the higher hydrophilicity of the cathode that leads to mass transfer

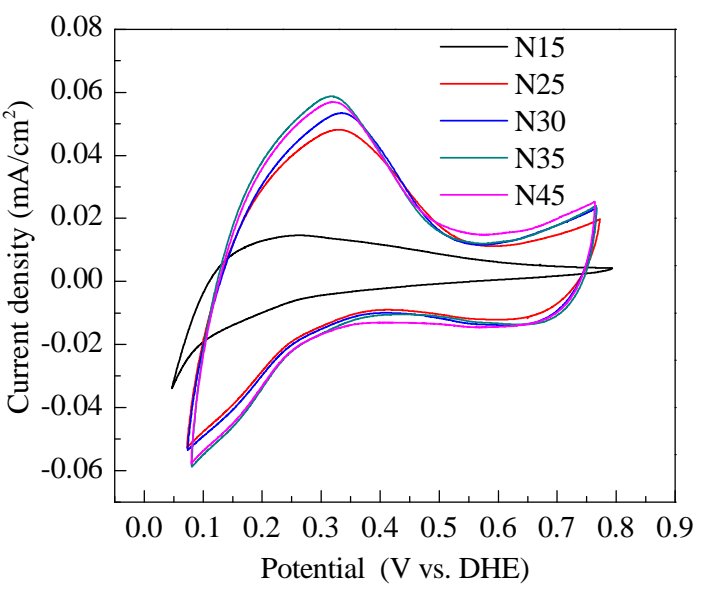

Fig. 4. In-situ CV curves for varying DMFCs as a function of Nafion content used in the cathode CL.

issues, i.e., water control becomes increasingly difficult as Nafion loading increases resulting in facile cathode flooding. According to the investigations made by Soboleva et al. [22], the ionomer co-deposition in the CL strongly influences the electrode porosity for pores sizes $<20 \mathrm{~nm}$. Therefore, mass transfer along the mesopores will be limited with excess ionomer, resulting in lower catalyst efficiency. When the operating temperature is raised to $70{ }^{\circ} \mathrm{C}$, the cell containing $30 \mathrm{wt} . \%$ Nafion (N30) still exhibits optimal performance, as shown in Fig. 5(b), with growing performance differences between the cells observed. Fig. 6 shows the differences in peak power densities between 60 and $70{ }^{\circ} \mathrm{C}$. The change in performance of N15 was insignificant between the two temperatures tested. In contrast, for $\mathrm{N} 30$, the performance increased by $15 \mathrm{~mW} / \mathrm{cm}^{2}$ as the proton conductivity of Nafion and catalytic activity increased with temperature.

In summary, DMFCs with varying ionomer loadings in the cathode CLs were fabricated and their the physical characteristics were studied according to their surface morphologies and contact angle measurements. CL roughness and thickness were shown to increase with the increasing of Nafion content. CLs
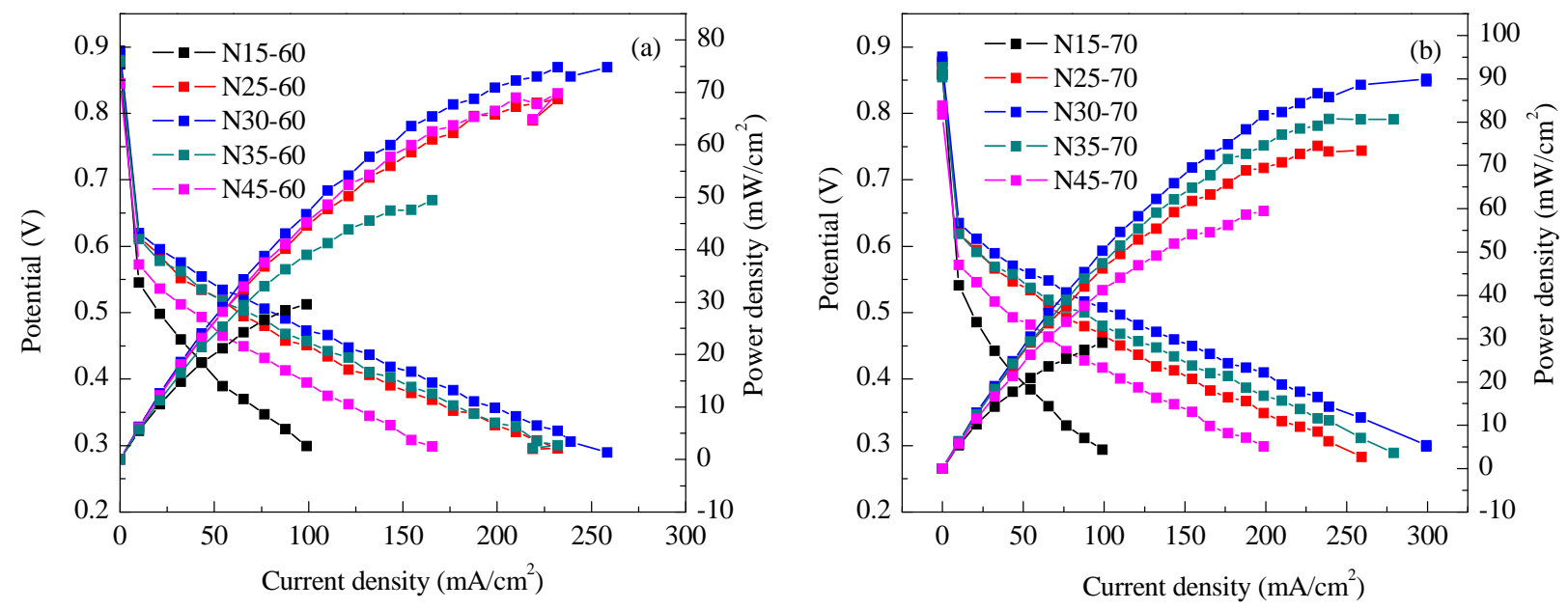

Fig. 5. Polarization curves of DMFCs with varying Nafion content at $60^{\circ} \mathrm{C}$ (a) and $70{ }^{\circ} \mathrm{C}$ (b). 


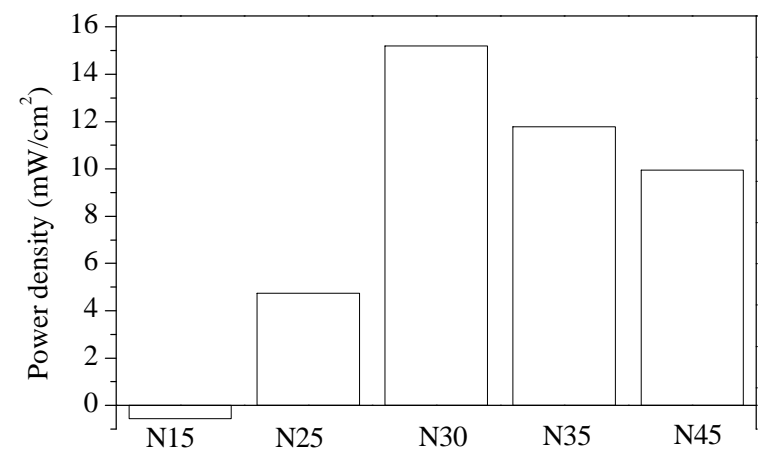

Fig. 6. Differences in peak power densities between 60 and $70{ }^{\circ} \mathrm{C}$.

with lower Nafion loading exhibited poor bonding with MPLs and proton exchange membranes. ESA increased as Nafion loading was increased, indicating higher catalyst utilization at elevated ionomer content. However, further increasing the ionomer content significantly affected hydrophilicity and the pore structure, which resulted in mass transfer issues. To improve the efficiency of CLs, proton conductivity and mass transfer should be considered simultaneously. This study found that a Nafion loading of $30 \mathrm{wt}$ \% yielded the optimal composition in the DMFC.

\section{References}

[1] X. Zhao, M. Yin, L. Ma, L. Liang, C. Liu, J. Liao, T. Lu, W. Xing, Energy Environ. Sci., 2011, 4, 2736-2753.

[2] N. Kakati, J. Maiti, S. H. Lee, S. H. Jee, B. Viswanathan, Y. S. Yoon, Chem. Rev., 2014, 114, 12397-12429.

[3] M. Chen, J. Chen, Y. Li, Q. H. Huang, H. F. Zhang, X. Z. Xue, Z. Q. Zou, H. Yang, Energy Fuels, 2012, 26, 1178-1184.
[4] Y. P. Sun, L. Xing, K. Scott, J. Power Sources, 2010, 195, 1-10.

[5] A. Arvay, E. Yli-Rantala, C. H. Liu, X. H. Peng, P. Koski, L. Cindrella, P. Kauranen, P. M. Wilde, A. M. Kannan, J. Power Sources, 2012, 213, 317-337.

[6] J. Kätzel, H. Markötter, T. Arlt, M. Klages, J. Haußmann, M. Messerschmidt, N. Kardjilov, J. Scholta, A. J. Banhart, I. Manke, J. Power Sources, 2016, 301, 386-391.

[7] S. J. Botelho, A. Bazylak, J. Power Sources, 2014, 269, 385-395.

[8] K. Miyazaki, T. Abe, K. Nishio, H. Nakanishi, Z. Ogumi, J. Power Sources, 2010, 195, 6500-6503.

[9] S. Holdcroft, Chem. Mater., 2014, 26, 381-393.

[10] J. Peron, Z. Q. Shi, S. Holdcroft, Energy Environ. Sci., 2011, 4, 1575-1591.

[11] M. El Hannach, T. Soboleva, K. Malek, A. A. Franco, M. Prat, J. Pauchet, S. Holdcroft, J. Power Sources, 2014, 247, 322-326.

[12] R. N. Bonifácio, A. O. Neto, M. Linardi, Int. J. Hydrogen Energy, 2015, 40, 2840-2849.

[13] S. Park, Y. Shao, H. Y. Wan, V. V. Viswanathan, S. A. Towne, P. C. Rieke, P. J. Liu, Y. Wang, J. Phys. Chem. C, 2011, 115, 22633-22639.

[14] W. K. Chao, R. H. Huang, C. J. Huang, K. L. Hsueh, F. S. Shieu, J. Electrochem. Soc., 2010, 157, B1012-B1018.

[15] Y. Y. Kang, M. J. Ren, T. J. Yuan, Y. Qiao, Z. Q. Zou, H. Yang, J. Power Sources, 2010, 195, 2649-2652.

[16] D. R. P. Morris, S. P. Liu, D. Villegas Gonzalez, J. T. Gostick, ACS Appl. Mater. Interfaces, 2014, 6, 18609-18618.

[17] S. Chabi, M. Kheirmand, Appl. Surf. Sci., 2011, 257, 10408-10413.

[18] R. N. Bonifácio, A. O. Neto, M. Linardi, Int. J. Hydrogen Energy, 2014, 39, 14680-14689.

[19] Q. R. He, N. S. Suraweera, D. C. Joy, D. J. Keffer, J. Phys. Chem. C, 2013, 117, 25305-25316.

[20] L. Xing, M. Mamlouk, R. Kumar, K. Scott, Int. J. Hydrogen Energy, 2014, 39, 9087-9104.

[21] T. Mashio, K. Sato, A. Ohma, Electrochim. Acta, 2014, 140, 238-249.

[22] T. Soboleva, X. S. Zhao, K. Malek, Z. Xie, T. Navessin, S. Holdcroft, ACS Appl. Mater. Interfaces, 2010, 2, 375-384.

\section{Graphical Abstract}

Chin. J. Catal, 2016, 37: 988-993 doi: 10.1016/S1872-2067(16)62481-6

\section{Cathode catalytic dependency behavior on ionomer content in direct methanol fuel cells}

Zhi Long, Guangrong Deng, Changpeng Liu, Junjie Ge, Wei Xing *, Shuhua Ma* Changchun Institute of Applied Chemistry, Chinese Academy of Sciences; University of Chinese Academy of Sciences; University of Jinan
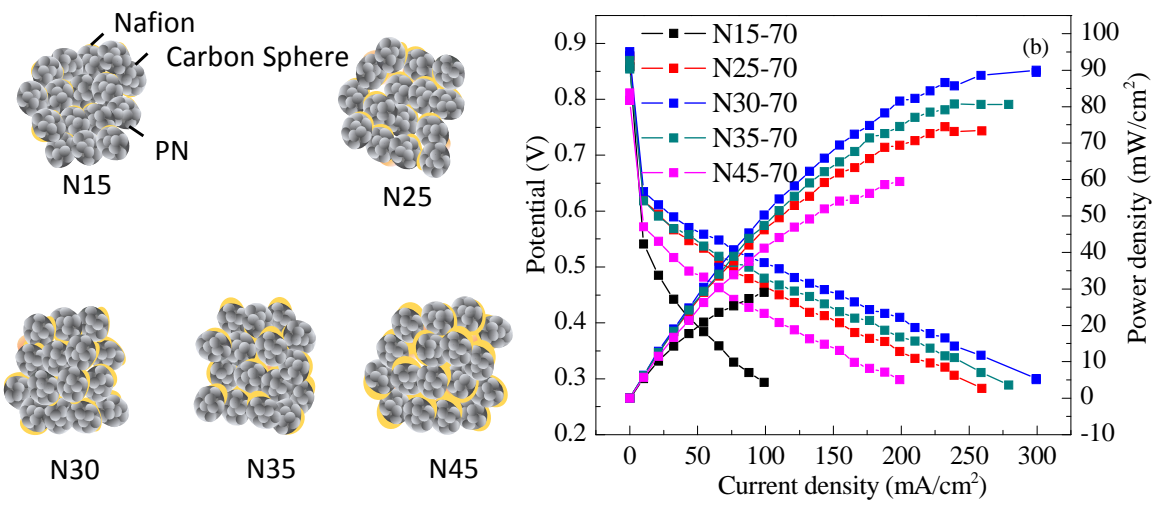

Cathode catalyst layers having low ionomer content hinders proton transfer, while high ionomer content limits the control of water and $\mathrm{O}_{2}$ mass transfer. Direct methanol fuel cells containing $30 \mathrm{wt}$.\% Nafion show optimal cell performance. 
[23] E. Passalacqua, F. Lufrano, G. Squadrito, A. Patti, L. Giorgi, Electrochim. Acta, 2001, 46, 799-805.

[24] G. H. Kim, K. S. Eom, M. J. Kim, S. J. Yoo, J. H. Jang, H. J. Kim, E. A. Cho, ACS Appl. Mater. Interfaces, 2015, 7, 27581-27585.

[25] G. S. Avcioglu, B. Ficicilar, A. Bayrakceken, I. Eroglu, Int. J. Hydrogen Energy, 2015, 40, 7720-7731.
[26] F. C. Cetinbas, S. G. Advani, A. K. Prasad, J. Power Sources, 2014, 270, 594-602.

[27] C. L. Lin, S. C. Hsu, W. Y. Ho, J. Mater. Sci. Chem. Eng., 2015, 3, 72-79.

[28] K. Lee, S. Ferekh, A. Jo, S. Lee, H. Ju, Electrochim. Acta, 2015, 177, 209-216.

\title{
Nafion 含量对直接甲醇燃料电池阴极催化剂性能表达的影响
}

\author{
龙 志, 邓光荣 ${ }^{\mathrm{a}, \mathrm{c}}$, 刘长鹏 ${ }^{\mathrm{a}, \mathrm{d}}$, 葛君杰 ${ }^{\mathrm{a}, \mathrm{d}}$, 邢 巍 ${ }^{\mathrm{a}, \mathrm{d}, *}$, 马树华 ${ }^{\mathrm{b}, \text {, }}$ \\ ${ }^{\mathrm{a}}$ 中国科学院长春应用化学研究所电分析化学国家重点实验室, 吉林长春 130022

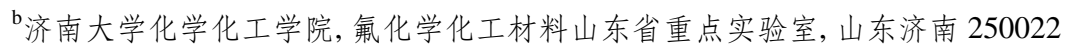 \\ c中国科学院大学, 北京 100049 \\ $\mathrm{d}$ 中国科学院长春应用化学研究所先进电源实验室, 吉林长春 130022
}

摘要: 燃料电池是一种将燃料反应的化学能转化为电能的装置, 可分为氢氧质子交换膜燃料电池 (PEMFCs)、直接甲醇燃 料电池 (DMFCs) 和直接甲酸燃料电池等. 与 PEMFCs 相比, DMFCs 以甲醇为燃料, 燃料的储存运输和电池操作运行具有 较高的安全性, 所以近年来受到人们的广泛关注.

膜电极组件 (MEA) 是 DMFCs 的核心部分, 由气体扩散层 (GDL)、催化层 (CL) 和质子交换膜 (PEM) 三部分组成. GDL 用于提高电池传质能力, 并同时作为 MEA 的集流体. PEM 主要用于隔离燃料和氧气, 进行质子传导. CL 是 MEA 中 的主要组成部分, 为电化学反应提供场所.

催化层由催化剂, 质子传输介质和电子传输介质组成. 通常, 阳极催化剂采用 $\mathrm{PtRu} / \mathrm{C}$, 阴极采用 $\mathrm{Pt} / \mathrm{C}$, 质子传输介质为 全氟磺酸树脂, 如 Nafion. CL 的结构对电池性能有直接的影响, 因此人们对 CL 的结构进行了详细的研究, 并通过调节 CL 亲水性能、梯度催化层的结构设计等优化其结构. 研究表明, 当 CL 中 Nafion 含量为 33 wt.\%, PEMFCs 具有最佳的电池性 能. DMFCs 与 PEMFCs 对 MEA 要求不同, 其阴极更容易发生水淹现象. 本文结合非接触式三维光学轮廓仪、接触角测试 系统和电化学测试对阴极不同 Nafion 含量的膜电极进行了表面形貌、亲水性、循环伏安和 DMFC 性能测试.

本文利用喷涂法制备了 GDE, 然后与 Nafion115 热压形成 MEA. 由三维表面形貌图可以看出, 随着催化层中 Nafion 含量的增加, GDE 表面的粗楉度变大, 尤其是 N35 和 N45. 理论上, 表面粗楉有利于 Pt 的暴露和传质扩散, 但是其电池性 能并未与粗粘度呈现出正相关的关系, 因为 Nafion 含量高于 $35 \mathrm{wt}$.\%, Pt 被 Nafion 过度包裏, 抑制了 $\mathrm{O}_{2}$ 至催化剂表面的传 输, 且随着 Nafion 含量由 15 wt.\% 增加至 45 wt.\%, 其 GDE 表面的接触角由 $166.8^{\circ}$ 减至 $143.1^{\circ}$, 说明 CL 的亲水性增强, 易 导致阴极产生的水无法及时排出, 从而造成阴极水淹现象.

从不同 Nafion 含量制备 MEA 的 CV 图可以看出, 随着 Nafion 含量的增加, Pt 的电化学活性面积 (ESA) 增加. 当 Nafion 含量较少时, Nafion 无法对全部 Pt 纳米粒子 (NPs) 形成包覆或无法形成连贯的质子传输通道, 从而导致大部分的 Pt NPs 催化活性较低变为无效 Pt. 而有效 Pt NPs 要求与连贯的质子传输通道相连接. 当 Nafion 含量高于 35 wt.\% 时, 其 ESA 基本保持不变, 因为 Pt 载量一定, 从而限制了 ESA, 此时达到该载量条件下的极限 ESA. 但是电池极化曲线表明, 30 wt.\% Nafion 含量的 MEA 具有最佳的电池性能. 因为有效 Pt NPs 不一定是高效的, 当他们全部被 Nafion 包裹后, $\mathrm{O}_{2}$ 只能 依靠溶解在 Nafion 中才可以到达催化剂表面, 从而阻碍传质. 只有 Pt NPs 表面包裹和暴露面积达到一定比例时才变得高 效. 所以当 Nafion 含量低于 $30 \mathrm{wt}$ \% 时, 主要由质子传输通道导致的有效 Pt NPs 较少; 当 Nafion 含量高于 30 wt.\% 时, 出 现 Nafion 过度包裹 Pt NPs, 阻碍 $\mathrm{O}_{2}$ 传质. 因此, Nafion 含量 30 wt.\% 时, Pt 的包裹面积和裸露面积达到所研究的最佳状态. 关键词: 直接甲醇燃料电池; 催化层; Nafion; 阴极; 离聚体

收稿日期: 2016-03-29. 接受日期: 2016-05-03. 出版日期: 2016-07-05.

*通讯联系人. 电话: (0431)85262223; 传真: (0431)85685653; 电子信箱: xingwei@ciac.jl.cn

\#通讯联系人. 电话: (0531)82769776; 电子信箱: chm_mashh@ujn.edu.cn

基金来源: 国家重点基础研究发展计划 (973 计划, 2012CB932800); 国家自然科学基金 (21433003, 21373199); 吉林省科技研究 项目 (20150101066JC, 20160622037JC).

本文的英文电子版由Elsevier出版社在ScienceDirect上出版(http://www.sciencedirect.com/science/journal/18722067). 